\title{
The Accounting Treatment of Rice Plant Biological Assets of Micro, Small, and Medium Enterprises (MSMEs) of Rice Farmers Groups
}

\author{
Hedy Rumambi*, Revleen Kaparang, Jerry Lintong, Joseph Tangon \\ Accounting Department \\ Manado State Polytechnic \\ Manado, Indonesia \\ *hedydr@yahoo.com
}

\begin{abstract}
This study was to identify the accounting treatment of rice plant biological assets in MSMEs of rice farmers groups. These entities have different characteristics from trading, service, or manufacturing entities due to their biological assets. This study used a qualitative research method with a descriptive approach. The object of this research is the groups of rice farmers in North Sulawesi. The data were collected through interviews also literature and document studies. We analyze the data through three stages, namely data reduction, data presentation, and concluding. The research result shows that the entity has not implemented an accounting system in its financial management. The accounting treatment is based on the Statement of Financial Accounting Standards (SFAS) No. 69, including recognition, measurement, presentation, and disclosure of biological assets. The accounting treatment identification refers to the scope of the business, business activities, and transactions. Rice plants as a biological asset are transformed biologically through rice planting activities. Biological assets of rice plants are recognized as inventories, measured at historical cost, presented as current assets in the financial position statement, and disclosed in a narrative or quantitative description in the notes of financial statements.
\end{abstract}

Keywords-MSMEs of rice farmers groups, rice plant biological assets, accounting treatment, SFAS No. 69

\section{INTRODUCTION}

An agricultural entity has assets that have unique characteristics and distinguish them from a trading, service, or manufacturing entity. These assets are biological assets because they undergo a biological transformation process through a growth process [1]. With this biological transformation, the actual value of an asset changes so that biological assets need unique measurements that can show the fair value of these assets by their contribution in generating a flow of economic profit to the company [2]. Rice plants are referred to as biological assets because they meet the SFAS No. 69 regarding biological assets consisting of living animals and or plants. The accounting treatment of biological assets includes recognition, measurement, presentation, and disclosure [3]. With ownership of biological assets, an entity is obliged to pay attention to these assets' accounting treatment by generally accepted accounting standards, considering that the results of this information will be reported in the financial statements for making economic decisions for interested parties [4]. MSMEs of rice farmers groups are one of the agricultural entities. In carrying out its activities, MSMEs' financial management is still not yet neatly organized. The financial records are carried out simply as limited as the amount of money going in and out [5]. Accounting recording made by MSMEs is still effortless [6]. They do not record their financial transactions. Besides that, they have main constraints in the high cost of raw materials, marketing difficulties, and lack of capital [7]. Previous studies focused on the accounting treatment for biological assets in plantation and livestock sector companies [8,9]. In contrast, this study focused on the agricultural sector for the MSMEs entity of rice farmers groups. This study aims to identify the accounting treatment of rice plant biological assets. The results of this identification will assist the MSMEs of rice farmers groups in building their accounting systems and compiling their financial reports.

\section{METHODS}

The research method is a qualitative method with a descriptive approach. We collect data through in-depth interviews with leaders of rice farmer groups in North Sulawesi. It is also through literature and document studies. The selection of informants was based on the consideration that North Sulawesi is one of Indonesia's rice-producing regions and has many rice farmer groups. The data collected includes the MSME's business scope, its activities, and the transactions that occur. After that, data analysis was carried out. Data analysis consists of data reduction, data presentation, and concluding [10]. Data reduction is made by summarizing, selecting, and focusing on the business scope, business activities, and transactions. The data presentation is focused on indicators of recognition, measurement, display, and disclosure of biological assets of rice plants based on SFAS No. 69 
adopted from IAS 41 Agriculture. Concluding was made to obtain the identifying result of the accounting treatment of rice plants' biological assets at the MSMEs of rice farmers groups.

\section{RESULTS AND DISCUSSION}

\section{A. Data of the Business Scope, Business Activities, and Transaction that Occur}

Based on the results of an in-depth interview with the informants, literature studies, and document studies, we found the following things in table 1 .

TABLE I. The Business SCOPE, Business ACtivitIES AND TRANSACTION THAT OCCUR IN MSMEs OF Rice FARMERS GROUPS

\begin{tabular}{|c|c|c|}
\hline Business Scope & Business Activities & Transaction that occurs \\
\hline \multirow{15}{*}{$\begin{array}{l}\text { They produce rice and also grain. } \\
\text { Every group include } 20-25 \text { members. } \\
\text { The level of education is junior and senior high schools. } \\
\text { The organizational structure consists of the chairman, } \\
\text { secretary, treasurer, and members. } \\
\text { The source of capital comes from government assistance } \\
\text { and group members. } \\
\text { The rice production cycle is three months. } \\
\text { The planting system is jajar legowo (Indonesian terms). } \\
\text { The land for rice planting is the agricultural land of the } \\
\text { members. } \\
\text { The bookkeeping in the form of a daily cashbook. } \\
\text { The purchase and selling transaction in cash and credit. } \\
\text { The sources of fixed assets are from members, rent, } \\
\text { purchasing, and government assistance. } \\
\text { The types of fixed assets such as agricultural land, } \\
\text { tractors/plow machine, and equipment such as thresher } \\
\text { tool, hand spray, and sickle. } \\
\text { The supplies include sacks, tarpaulins, nets, and pans. }\end{array}$} & Rice Planting & \\
\hline & Land preparation & $\begin{array}{l}\text { Rent of plow machine } \\
\text { Purchase of plow machine } \\
\text { Payment of worker's wages } \\
\text { Purchase of fertilizer } \\
\text { Purchase of fuel (gasoline or solar) } \\
\text { Provision of agricultural land }\end{array}$ \\
\hline & Nursery & $\begin{array}{l}\text { Purchase of seeds } \\
\text { Get of seeds donation } \\
\text { Payment of worker's wages }\end{array}$ \\
\hline & Planting & $\begin{array}{l}\text { Purchase rope } \\
\text { Payment of wages }\end{array}$ \\
\hline & Maintenance & $\begin{array}{l}\text { Payment of worker's wages } \\
\text { Purchase of pest drugs } \\
\text { Purchase of pest spray tool } \\
\text { Purchase of fertilizer } \\
\text { Purchase of nets }\end{array}$ \\
\hline & Rice Harvest & \\
\hline & Rice harvest & $\begin{array}{l}\text { Payment of worker's wages } \\
\text { Purchase of tarp } \\
\text { Purchase of harvest tool }\end{array}$ \\
\hline & Rice Threshing & $\begin{array}{l}\text { Payment of worker's wages } \\
\text { Payment of vehicle rent } \\
\text { Purchase of tarp, pans, and sacks }\end{array}$ \\
\hline & Rice Post-Harvest & \\
\hline & Drying & Payment of worker's wages \\
\hline & Milling & $\begin{array}{l}\text { Expense of equipment rent for milling the } \\
\text { yields } \\
\text { Payment of transportation to transport the } \\
\text { yields to the milling place }\end{array}$ \\
\hline & Selling & $\begin{array}{l}\text { Rice selling } \\
\text { Grain selling }\end{array}$ \\
\hline & Other activities & \\
\hline & Sources of capital & $\begin{array}{l}\text { Government Aid } \\
\text { Member of the group }\end{array}$ \\
\hline & Cash and credit transaction & $\begin{array}{l}\text { Cash transaction } \\
\text { Credit transaction (purchasing) } \\
\text { Credit transaction (selling) }\end{array}$ \\
\hline
\end{tabular}

\section{B. MSMEs of Rice Farmers Groups as an Entity}

Entities are separate from their owners [11]. This theory emphasizes the separation of the entity from the parties that provide capital. Therefore, the entity as a business unit has responsibility for the interests of both owners and creditors. The management of the entity carries out this responsibility by measuring its financial performance [12]. This form of accountability is also carried out through clearly financial management to provide accurate and relevant information.

An entity must consider a business entity's concept as its essential thinking to make financial statements [5]. That's why it needs to make the company clearly between the business owner and its business entity. Owner transactions must be separated from the entity business transactions [13]. The company is divided and different entity from its owner [14].

MSMEs of rice farmers groups as an entity which are separated from their members. That's why the MSMEs management should provide their accountability and accounting information's in financial statements. The report's components are generally related to the accounting treatment consisting of recognition, measurement, presentation, and disclosure $[3,13]$. 


\section{Rice Plant as a Biological Assets}

SFAS No. 69 Agriculture defines biological assets as animals or plants living in agricultural activities [3]. Agriculture activity manages biological transformation and harvesting of biological assets by entities for sale or conversion into agricultural products or additional biological assets. Biological assets continue to change because they grow, decline, and produce. This series of processes is referred to as biological transformation, namely process, growth, degeneration, production, and procreation, which cause qualitative or quantitative changes in biological assets $[3,15]$. Rice plants as a biological asset in agricultural activities [3]. Rice agricultural activities are carried out through biological transformation management for growing rice plants. The biological transformation process in rice plants, namely rice planting activities, includes land preparation, nursery, planting, and maintenance. These process increasing the quantity and improving the quality of rice plants. This biological transformation becomes the main character of biological assets and what distinguishes them from other fixed assets.

Biological assets are classified as generating or immature biological assets [3]. Productive biological assets have reached the specifications for harvesting (for biological assets that can be consumed) or can produce a sustainable harvest (for productive biological assets). Immature biological assets can be defined as assets that are still in their infancy and immature or have not yet entered productive age. Biological assets are classified as non-current assets [16].

However, the biological assets' presentation is still divided based on their transformation period or economic period in its application. They can be classified into current assets or noncurrent assets. The financial statements can be grouped according to their biological transformation period [17], namely short term and long term biological assets. If the useful lives of biological assets less than or up to 1 year, they are classified as current assets and are included in inventories or other current assets. Conversely, if the company's useful life is more than one year, the biological assets are classified as noncurrent assets and classified into other assets.

The biological assets of rice plants are not productive plants because they have an age for only one planting period that is three months. It is different from other productive plants such as oil palm trees, which have a productive age of more than one year. With the age of one planting period, rice plants' accounting treatment is not classified as immature plants. The useful lives of rice plants are the basis of classification and are classified as current assets.

\section{Biological Assets Recognition}

Recognition is a component of accounting treatment. Recognition is the process of determining whether an account that meets an element's definition is stated in the balance sheet or the comprehensive income statement $[3,13]$. Recognition determines when an account will be presented so that the consequence is that the recording of the transaction must be done.

Recognition is selecting an account by a transaction carried out by an entity to be stated in the report. The accounts selection must be adjusted into characteristics of the entity's transactions with the accounts' definition to be classified and adjusted according to these transactions $[3,13]$. If a sacrifice or transaction may result in future benefits, it can be classified into an asset account. However, if the circumstances are inversely proportional, these sacrifices can be classified into several expenses stated in the income statement.

Recognition is the process of reporting a business that meets the definitions, the criteria for recognition, as stated in the elements of financial statements in either the financial statements or the income statement. The recognition of rice plants as a biological asset starts from planting activity to the point of harvest.

Based on the data, the biological transformation of rice plants occurs in all rice planting activities. These activities start with land preparation, nursery, planting, and maintenance. All transactions related to these activities are recorded in the ricebiological inventory account. Inventory is an asset available for sale in the ordinary course of business, in the production process for that sale, in the form of materials or equipment for use in the production process or rendering services.

This account is to seek all transactions that affect the plant growth process so that rice plants are ready to be harvested and sold. The recognition of rice as a biological inventory because the entity controls biological assets due to past events, the future economic benefits associated with the biological assets will probably flow to the entity, and the fair value or cost of the biological assets can be measured in a quantifiable manner. Recognition of the biological assets of rice plants can be seen in table 2.

TABLE II. RECOGNITON OF Rice Plant BIOLOGICAL ASSET

\begin{tabular}{|c|c|c|}
\hline $\begin{array}{l}\text { Business } \\
\text { Activities }\end{array}$ & Transaction that occurs & $\begin{array}{c}\text { Recognition of } \\
\text { Rice Plant } \\
\text { Biological Asset }\end{array}$ \\
\hline \multicolumn{3}{|l|}{ Rice Planting } \\
\hline $\begin{array}{l}\text { Land } \\
\text { preparation }\end{array}$ & $\begin{array}{l}\text { Rent of plow machine } \\
\text { Purchase of plow machine } \\
\text { Payment of worker's wages } \\
\text { Purchase of fertilizer } \\
\text { Purchase of fuel (gasoline or solar) } \\
\text { Provision of agricultural land }\end{array}$ & \multirow[t]{4}{*}{$\begin{array}{l}\text { Inventory of } \\
\text { Biological } \\
\text { Assets-Rice Plant }\end{array}$} \\
\hline Nursery & $\begin{array}{l}\text { Purchase of seeds } \\
\text { Get of seeds donation } \\
\text { Payment of worker's wages }\end{array}$ & \\
\hline Planting & $\begin{array}{l}\text { Purchase rope } \\
\text { Payment of wages }\end{array}$ & \\
\hline Maintenance & $\begin{array}{l}\text { Payment of worker's wages } \\
\text { Purchase of pest drugs } \\
\text { Purchase of pest spray tool } \\
\text { Purchase of fertilizer } \\
\text { Purchase of nets }\end{array}$ & \\
\hline
\end{tabular}




\section{E. Biological Assets Measurement}

The measurement of biological assets is carried out by determining the amount of money from the inventory of biological assets to be presented in the financial position [4]. This process involves selecting a specific measurement basis. The various bases for these measurements are historical cost, current cost, realizable or settlement value, present value or fair value. The measurement basis commonly used by an entity in preparing its financial statements is the historical cost [13]. Biological assets are measured at initial recognition, and the end of each reporting period at fair value, fewer costs to selling [3].

Companies can use the fair value in case of availability of the active market to assess biological assets and agricultural products, but nowadays, the active agricultural market is mostly unavailable. This condition pushes companies to use another measurement as their accounting policy [18]. Historical costs become the accounting policy used to measure biological assets in the MSMEs of rice farmer groups.

Assets are recorded at the amount of cash disbursed to acquire the assets when they are accepted. It is intended to make it easier for rice farmers groups to take measurements. The use of historical costs due to the level of education of MSMEs managers.

\section{F. Biological Assets Presentation and Disclosure}

An entity shall present a reconciliation of changes in the carrying amount of biological assets between the beginning and the end of the current period. Disclosure of each group of biological assets can be in the form of a narrative or quantitative description [3]. The presentation and disclosure of rice plants assets information were done through the financial statement.

A financial statement is a tool to present financial information [19]. An opinion regarding property and its financial position is formed from the completed, objective, and reliable financial statement [20]. The financial statement uses a tool, analytical technic, and the method needed for business analysis [21]. Financial information is useful for various users in making an economic decision [22]. Financial reports are helpful if presented in a relevant, reliable, and consistent manner [23]. The minimum financial statement consists of a financial position statement at the end of the period, the income statement for the period, and the notes of financial statements [13]. To disclose the biological assets, MSMEs use the notes of financial statements.

Rice plant assets can be grouped according to their biological transformation period. Rice plant asset's useful life is less than or up to one year; therefore, it is classified as current assets (inventories) or other current assets.

Therefore, MSMEs present their biological assets in the financial position statement in the current assets category and are recorded in the inventory account. The presentation as current assets because rice plants have an age for only one planting period. The rice production cycle is three months. The value of biological assets in the company's financial position statement is recorded at the cost of the biological assets. The example of the statement of financial position is presented in table 3 .

TABLE III. The StATEMENT OF FinANCIAL Position

\begin{tabular}{|c|c|c|}
\hline \multicolumn{3}{|c|}{$\begin{array}{c}\text { RICE FARMERS GROUPS OF MSMEs } \\
\text { Financial Position Statement } \\
\text { March, } 312020\end{array}$} \\
\hline ASSETS & & \\
\hline CURRENT ASSETS & & \\
\hline Cash & $\mathrm{xxx}$ & \\
\hline Account Receivable & $\mathrm{xxx}$ & \\
\hline Inventory of Seeds & $\mathrm{xxx}$ & \\
\hline $\begin{array}{l}\text { Inventory of Biological } \\
\text { Assets-Rice Plant }\end{array}$ & $\mathrm{xxx}$ & \\
\hline
\end{tabular}

According to Financial Accounting Standard for MSMEs, disclosures are made on the notes of financial statements. Disclosures of biological assets can be in the form of narrative or quantitative descriptions [3]. MSMEs can describe the nature of biological assets' activity, the elements that form the value of biological assets, and the output of agricultural products during that period. The example of the notes of financial statements in table 4.

\section{TABLE IV. The Notes of FinANCial StATEMENT}

\begin{tabular}{|l|}
\hline $\begin{array}{l}\text { RICE FARMERS GROUPS OF MSMEs } \\
\text { Notes of Financial Statement } \\
\text { Per March, 31 2020 }\end{array}$ \\
\hline GENERAL \\
\hline $\begin{array}{l}\text { SUMMARY OF ACCOUNTING POLICIES } \\
\text { Inventory of biological assets: } \\
\text { Inventory measurement using historical cost }\end{array}$ \\
\hline CASH \\
\hline ACCOUNT RECEIVABLE \\
\hline INVENTORY OF SEEDS \\
\hline $\begin{array}{l}\text { INVENTORY OF BIOLOGICAL ASSETS-RICE PLANT } \\
\text { The rice production cycle is three months } \\
\text { The elements forming the value of biological assets such as Purchase of } \\
\text { seeds, Seeds donation, Payment of worker's wages, etc } \\
\text { The output of activity agriculture is rice and grain }\end{array}$ \\
\hline
\end{tabular}

MSMEs of rice farmers groups are separate entities from their owners. Therefore, MSME financial management cannot be limited to recording cash in and out in a daily cash book. To be accountable for their financial management, MSMEs need to prepare financial reports. Accounting treatment for rice plants' biological assets is an important aspect in the preparation of MSME financial reports. Said to be an important aspect because this type of MSME is an agricultural entity. Its business activities focus on agricultural activities through biological transformation management and producing agricultural products. These agricultural activities include rice planting, rice harvesting, and rice post-harvest. Rice planting 
activities illustrate rice plants' biological transformation consisting of land preparation, nursery, planting, and maintenance activities. These four activities describe the process of growing the rice plant so that it is ready for harvest.

In general, differences in each company's biological assets can cause differences in recording biological assets. The differences are in plant type, plant age, and cost incurred in each plant type [24]. The measurement and reporting of biological assets can be very heterogeneous and can be influenced by race, life cycle stages, health status, productivity, and more. The relevance of financial information depends on these influences [25]. Therefore, identification of the accounting treatment of rice plant biological assets refers to all rice planting activities.

\section{CONCLUSION}

Agricultural entities have unique characteristics of assets that are different from other entities. Rice plants are classified as biological assets because they undergo biological transformation through their growth. This biological transformation is illustrated through rice planting activities and becomes the starting point for the identification of the accounting treatment of rice biological assets. The recognition of rice plants as a biological asset starts from the time of planting activities to the point of harvest, namely land preparation, nursery, planting, and maintenance. The account used to recognize transactions related to these activities is the rice plants' inventory of biological assets. The measurement uses historical costs. Assets are recorded at the amount of cash disbursed to acquire assets when they are accepted. The inventory of the biological assets-rice plant is presented in the financial position statement as current assets and grouped into an inventory account with a value equal to the asset's cost. The disclosures can be in the form of a narrative description (the nature of biological assets' activity, the elements forming the value of biological assets, and the output of agricultural products) or quantitative description in the notes of the financial statement. The criteria used in the recognition, measurement, presentation and disclosure of rice plant biological assets are carried out simply according to the business scope, business activity, and transactions that occur from the entity to make it easier for MSMEs in their application. The results of the identification of the accounting treatment of rice biological assets can be used as a reference by the MSMEs of rice farmers groups in building an accounting system and preparing their financial reports.

\section{ACKNOWLEDGMENT}

We would like to deeply thank to Directorate of Research and Community Service, Directorate General of Strengthening Research and Development, Ministry of Research, Technology and Higher Education of the Republic of Indonesia who has provided funding for our research. Sincere thanks are also rendered to the Center of Research and Community Service of Manado State Polytechnic that has facilitated this research.

\section{REFERENCES}

[1] R. Utomo and N.L. Khumaidah, "Perlakuan akuntansi aset biologis (tanaman kopi) pada PT. Wahana Graha Makmur - Surabaya," Gema Ekonomi Jurnal Fakultas Ekonomi, vol. 3, no. 1, 2014.

[2] D.P. Eltanto, "Perlakuan akuntansi dan pph atas industri agrikultur," Tax \& Accounting Review, vol. 4, no. 1, 2014

[3] Statement of Financial Accounting Standards No. 69, Agriculture, Jakarta: Institute of Indonesia Chartered Accountants (IAI), 2018.

[4] H. Kartikahadi, Rosita, U. Sianaga, E.T. Wahyuni, and S.V. Siregar, Financial accounting based on IFRS-SAK, Second Edition, Book 1. Jakarta: Institute of Indonesia Chartered Accountants, 2016.

[5] H. Rumambi, R. Kaparang, J. Lintong, and J. Tangon, "The building blocks to construct financial statements of micro, small, and medium enterprises (MSMEs) of rice farmers groups," International Journal of Academic Research in Accounting, Finance and Management Sciences, vol. 9, no. 4, pp. 1-9, 2019.

[6] S.T. Risnaningsih and N.I. Iriani, "Improving transparency and accountability of MSME financial statements by using the accrual method," Management and Economics Journal, vol. 2, no. 2, August 2018 .

[7] T. Tambunan, "Development of micro, small and medium enterprises and their constraints: A story from Indonesia," Gadjah Mada International Journal of Business, vol. 13, no. 1, pp. 21-43, 2011.

[8] R. Wulandari and F.L. Wijayati, "Analisis perlakuan akuntansi aset biologis pada perusahaan sektor agrikultur subsektor perkebunan yang terdaftar di Bursa Efek Indonesia (BEI)," Riset Akuntansi dan Keuangan Indonesia, vol. 3, no. 2, pp. 159-176, 2018

[9] R. Listyawati and A. Firmansyah, "Evaluasi penerapan akuntansi aset biologis pada perusahaan sektor peternakan," Substansi, vol. 2, no. 1, pp. 59-76, 2018.

[10] M.B. Miles, A.M. Huberman, and J. Saldana, Qualitative data analysis: A methods source book, Edition 3. Sage Publication Inc, 2014.

[11] S.S. Harahap, Teori akuntansi, Edisi Revisi. Jakarta: PT. Raja Grafindo Persada, 2012.

[12] Suwardjono, Accounting theory: financial reporting engineering, Third edition. Yogyakarta: BPFE, 2014. (Suwardjono, Teori akuntansi: perekayasaan pelaporan keuangan, Edisi Ke-3. Yogyakarta: BPFE, 2014).

[13] Institute of Indonesia Chartered Accountants, Financial Accounting Standards for Micro, Small, and Medium Entities. Jakarta: IAI, 2018. (Ikatan Akuntan Indonesia, Standar Akuntansi Keuangan Entitas Mikro, Kecil dan Menengah. Jakarta: IAI, 2018).

[14] D.E. Kieso, J.J. Weygandt, and T.D. Warfield, Intermediate accounting IFRS edition. John Wiley \& Sons, Inc, 2011

[15] N. Ankarath, K.J. Mehta, T. Ghosh, and Y.A. Alkafaji, Understanding IFRS: International Financial Reporting Standards. Jakarta: Index, 2015.

[16] J.J. Weygandt, P.D. Kimmel, D.E. Kieso, Financial Accounting: IFRS Edition, 3th Edition. New York: John Willey \& Sons Inc, 2015.

[17] N.W.Y. Dewi dan G.A.R.S. Dewi, "Analysis of the accounting system for biological assets of aquaculture companies (Case study on CV. Dewata Laut)," in the National Seminar on Innovative Research, 2017. (N.W.Y. Dewi dan G.A.R.S. Dewi, "Analisis sistem akuntansi aset biologis perusahaan akuakultur (Studi kasus pada CV. Dewata Laut),' dalam Seminar Nasional Riset Inovatif, 2017).

[18] L. Sabauri and E. Kharabadze, "Methods of accounting and assessment of the biological assets and agricultural products in the absence of an active market (by the International Accounting Standards)," Presented at 17th International Academic Conference, Viena, Austria, June 21th, 2015.

[19] F. Didin, Jusni, and M. Mochamad, "How to measure financial performance," International Journal of Civil Engineering and Technology, vol. 9, no. 6, pp. 553-557, 2018.

[20] I.E. Thalassinos and K. Liapis, Segmental financial reporting and the internationalization of the banking sector. Chapter book in, Risk 
Management: Strategies for Economic Development and Challenges in the Financial System, (eds), D. Milos Sprcic, Nova Publishers, pp. 221255, 2014.

[21] P. Hasanaj and B. Kuqi, "Analysis of financial statements: the importance of financial indicators in entity," Humanities and Social Science Research, vol. 2, no. 2, pp. 17-27, 2019.

[22] P.V.C. Okoye and C.O. Akenbor, "Financial reporting framework in Nigeria and the adoption of the international financial reporting standards," International Journal of Business and Economic Development, vol. 2, no. 1, pp. 52-63, 2014.
[23] Md. Azim and J. Ara, "Accountability of accounting stakeholders," Global Journal of Management and Business Research, vol. 15, no. 2, pp. 4-10, 2015.

[24] N.W. Widiyanti, B. Maharani, and I. Purnamawati, "Accounting treatment of biological assets for agricultural companies in Jember and Bondowoso," International Journal of Finance and Banking Studies, vol. 7, no. 2, pp. 58-65, September 2018.

[25] B. Savic and N. Obradović, "Challenges in financial reporting about biological assets," Oditor - casopis za Menadzment finansije i pravo, vol. 6, no. 1, pp. 7-21, January 2020. 